\title{
INDUÇÃO DE CALO A PARTIR DE EIXO EMBRIONÁRIO DE COQUEIRO (Cocos nucifera L.) $)^{1}$
}

\author{
KICIA KARINNE PEREIRA GOMES $S^{2,3}$, VIRGÍNIA CARLA DE OLIVEIRA ${ }^{3,4}$, ANA DA SILVA LEDO ${ }^{3,5}$ \\ PAULA CRISTINA DA SILVA ÂNGELO ${ }^{3,6}$, JEFFERSON LUÍS DA SILVA COSTA ${ }^{3,7}$
}

\begin{abstract}
RESUMO - Este estudo teve como objetivo avaliar a capacidade de formação de calos a partir de tecidos originários do eixo embrionário de embriões zigóticos de coqueiro (Cocos nucifera L.) em diferentes concentrações de 2,4-D. O experimento foi instalado em delineamento inteiramente casualizado, em esquema fatorial 4x5 (4 concentrações de 2,4-D x 5 segmentos do eixo embrionário). Os eixos embrionários foram excisados longitudinalmente dos embriões zigóticos e, em seguida, submetidos à assepsia com hipoclorito de sódio $(0,2 \%)$ por dois minutos, lavados com água destilada estéril e imersos por dois minutos em solução de ácido cítrico estéril $\left(100 \mathrm{mg} . \mathrm{L}^{-1}\right)$. Os eixos embrionários foram então seccionados em cinco segmentos correspondentes às posições A, B, C, D e E, e transferidos para placas de Petri contendo meio de cultura Y3, suplementado com quatro concentrações de 2,4-D (10-4; 1,36x 10$\left.{ }^{4} ; 3,62 \times 10^{-4} \mathrm{e} 4,52 \times 10^{-4} \mathrm{M}\right)$, sacarose $\left(50 \mathrm{~g} . \mathrm{L}^{-1}\right)$, carvão ativado $\left(2,5 \mathrm{~g} . \mathrm{L}^{-1}\right)$ e vitaminas de Morel e Wetmore, mantidos em ambiente escuro, em temperatura de $25 \pm 2^{\circ} \mathrm{C}$. Após 15 dias de inoculação, os segmentos Ae B apresentaram 97,5\% de explantes com calos friáveis na concentração de $10^{-4} \mathrm{M}$ de $2,4-\mathrm{D}$, e $92,5 \%$ e $80 \%$, respectivamente, na concentração de 1,36x10-4 M. O segmento E, em ambas as concentrações, apresentou 60\% de calogênese. Após 30 dias de inoculação, os segmentos Ae B apresentaram $100 \%$ e $97,5 \%$ de calogênese na concentração de $10^{-4} \mathrm{M}$, e $90 \%$ e $80 \%$, respectivamente, na concentração de 1,36x $10^{-4} \mathrm{M}$. Em ambas as concentrações, o segmento E apresentou de 55 a 57,5\% de formação de calos. As concentrações de 2,4-D que melhor induzem calogênese, são as de $10^{-4}$ e 1,36×10-4 M. Os segmentos A, B e E apresentaram maior competência para calogênese.
\end{abstract}

Termos para indexação: Cultura de tecidos, reguladores de crescimento, cultura in vitro

\section{CALLUS INDUCTION FROM COCONUT EMBRYOGENIC AXIS (Cocos nucifera L.)}

ABSTRACT - The ability of callus formation from the embryo axes of coconut in different concentrations of 2,4-D was evaluated. The experimental design was completely randomized in a $4 \times 5$ factorial scheme ( 4 concentrations of 2,4-D x 5 segments of the embryogenic axis). The axes were excised longitudinally out of zigotic embryos and were then disinfected with sodium hipocloride $(0.2 \%)$ for two minutes, washed with sterile distilled water, and soaked for two minutes in a solution of sterile citric acid $\left(100 \mathrm{mg} . \mathrm{L}^{-1}\right)$. The embryogenic axes were split in five segments corresponding to positions A, B, $\mathrm{C}, \mathrm{D}$ and $\mathrm{E}$, and transferred to Petri dishes containing the culture media Y3, suplemented with four concentrations of 2,4-D $\left(10^{-4} ; 1.36 \times 10^{-4} ; 3.62 \times 10^{-4}\right.$; $\left.4.52 \times 10^{-4} \mathrm{M}\right)$, sucrose $\left(50 \mathrm{~g} . \mathrm{L}^{-1}\right)$, activated charcoal $\left(2.5 \mathrm{~g} . \mathrm{L}^{-1}\right)$ and vitamins of Morel and Wetmore. The Petri dishes were incubated in a dark atmosphere under the temperature of $25 \pm 2^{\circ} \mathrm{C}$. After 15 days of inoculation, the segments $\mathrm{A}$ and $\mathrm{B}$ in the concentration of $10^{-4} \mathrm{M}$ of $2,4-\mathrm{D}$ presented $97.5 \%$ of explants with friable callus, and $92,5 \%$ and $80 \%$, respectively, in the concentrations of $1.36 \times 10^{-4} \mathrm{M}$ of 2,4-D. The E segment, in both concentrations, presented $60 \%$ of callus formation. After 30 days of inoculation, the segments A and B promoted $100 \%$ and $97.5 \%$ in the concentration of $10^{-4} \mathrm{M}$, and $90 \%$ and $80 \%$, respectively, in the concentrations of $1.36 \times 10^{-4} \mathrm{M}$. The E segment promoted $55 \%$ to $57.5 \%$ of callus induction in both concentrations.

Index terms: Tissue culture, growth regulators, in vitro culture

\section{INTRODUÇÃO}

Apesar da importância do coco (Cocos nucifera L.) no cenário mundial, no Brasil e no Nordeste, a sua produtividade ainda é extremamente baixa, sendo ocasionada, principalmente, pelo uso de cultivares não selecionadas, nutricionais, manejo inadequado de água e por problemas fitossanitários que diminuem significativamente a área foliar, promovendo perdas de até $50 \%$ na produção da cultura no País (Siqueira et al., 1995).

As técnicas de cultura de tecidos têm sido aplicadas de diferentes formas em programas de melhoramento, na conservação e avaliação de germoplasma, aumento da variabilidade genética para fins de seleção, na introgressão de genes de interesse, para acelerar programas de melhoramento e na clonagem de genótipos. Dentre todas as aplicações da cultura de tecidos de plantas, sem dúvida, as de maior impacto são as de utilização no melhoramento genético de plantas e na recuperação de plantas livres de vírus e outros agentes fitopatogênicos (Sá et al., 2000).

A propagação clonal do coqueiro tem sido alvo de estudos nos últimos 20 anos por organizações de pesquisa pública e privada. Essas pesquisas têm se concentrado na obtenção de protocolos de multiplicação in vitro a partir da embriogênese somática e organogênese, em todos os tipos de tecidos meristemáticos e a partir da reversão floral (Branton \& Blake, 1986; Buffard-Morel et al., 1988; Verdeil et al., 1994; Blake \& Hornung, 1995; Hornung, 1995). A técnica de clonagem apresenta enorme importância prática por produzir plantas mais uniformes, sadias e em uma velocidade muito maior do que os métodos convencionais. Algum sucesso tem sido obtido com a cultura in vitro de embriões zigóticos de coco, técnica que pode ser usada para conservação e intercâmbio de germoplasma e para propagação de híbridos raros (Rillo \& Paloma, 1990).

A propagação vegetativa do coqueiro por meio de cultura de tecidos poderá permitir significativos aumentos de produtividade pela multiplicação de indivíduos produtivos, resistentes a doenças ou dotados de uma particular capacidade de adaptação a condições adversas de ambiente (Pannetier \& Buffard-Morel, 1986).

Eeuwens (1978) verificou a influência da nutrição orgânica e dos reguladores de crescimento nos explantes de tecido de inflorescência. Os resultados mostraram que reguladores de crescimento, tais como o 2,4-D (2,4-diclorofenoxiacético) e ANA (ácido naftaleno acético), estimularam o crescimento dos tecidos apenas em baixas concentrações e que sua presença em altas concentrações causou a morte dos tecidos. Além do crescimento dos explantes, diferentes tipos de proliferações foram obtidos, como formação de calo na parte superior de explantes com caule, folhas e inflorescência (Eeuwens, 1976). Chan et al. (1998) estabeleceram protocolo de regeneração de coco por embriogênese somática, usando plúmulas de embriões zigóticos como explante, combinando reguladores de crescimento, 2,4-D e BAP (6-benzilaminopurina), no meio de cultura.

O objetivo do presente estudo foi avaliar a capacidade de formação de calos a partir de tecidos originários do eixo embrionário de embriões zigóticos de coqueiro-Anão Verde de Jiqui em diferentes

\footnotetext{
${ }^{1}$ (Trabalho 077/2003). Recebido: 25/06/2003. Aceito para publicação: 04/12/2003.

2 Bolsista PIBIC/CNPq, kicia@cpatc.embrapa.br,

${ }^{3}$ Embrapa Tabuleiros Costeiros, CEP 49001-970 Aracaju-SE

${ }^{4}$ Bolsista/AT-CNPq, vcarla@ cpatc.embrapa.br, Tel.: (79) 226-1345

${ }^{5}$ Eng. Agr., D.Sc., Pesquisadora, analedo@cpatc.embrapa.br, Tel.: (79) 226-1318

${ }^{6}$ Biol., D.Sc., Pesquisadora, paula@ cpaa.embrapa.br, Tel.: (92) 621-0419

${ }^{7}$ Eng. Agr., PhD, Pesquisador, Bolsista PQ do CNPq, jcosta@cpatc.embrapa.br, Tel.: (79) 226-1359
} 
concentrações de 2,4-D.

\section{MATERIAL E MÉTODOS}

Foram utilizados eixos embrionários obtidos a partir de embriões zigóticos maduros de plantas de coqueiro-Anão Verde de Jiqui provenientes do Banco de Germoplasma da Embrapa Tabuleiros Costeiros, localizado no Campo Experimental do Betume, em Neópolis-SE. O experimento foi instalado em delineamento inteiramente casualizado, em esquema fatorial 4 x 5 (quatro concentrações de 2,4-D combinadas com cinco segmentos do eixo embrionário), com quatro repetições, sendo cada parcela experimental composta por dez placas de Petri com cinco segmentos cada.

Os eixos embrionários foram excisados longitudinalmente, dos embriões zigóticos sem corte dos primórdios foliares, em câmara de fluxo laminar, com o auxílio de um microscópio estereoscópio. Em seguida, foram submetidos à assepsia com hipoclorito de sódio $(0,2 \%)$, por dois minutos, lavados com água destilada estéril, por três vezes, e imersos por dois minutos em solução de ácido cítrico estéril (100 mg.L $\left.\mathrm{L}^{-1}\right)$. Os eixos embrionários foram então seccionados em cinco segmentos correspondentes às posições A (porção apical), B, C, D e E (porção basal) (Figura 1), e transferidos para placas de Petri contendo meio de cultura Y3 (Eeuwens, 1976), suplementado com quatro concentrações de 2,4-D $\left(10^{-4}\right.$; $\left.1,36 \times 10^{-4} ; 3,62 \times 10^{-4} \mathrm{e} 4,52 \times 10^{-4} \mathrm{M}\right)$, sacarose $\left(50 \mathrm{~g} . \mathrm{L}^{-1}\right)$, carvão ativado $(2,5$ g. $\left.\mathrm{L}^{-1}\right)$ e vitaminas de Morel \& Wetmore (1951). As placas contendo os explantes foram mantidas em sala de crescimento, com temperatura variando de $25 \pm 2^{\circ} \mathrm{C}$, umidade relativa do ar média em torno de $70 \%$ e ausência total de luz.

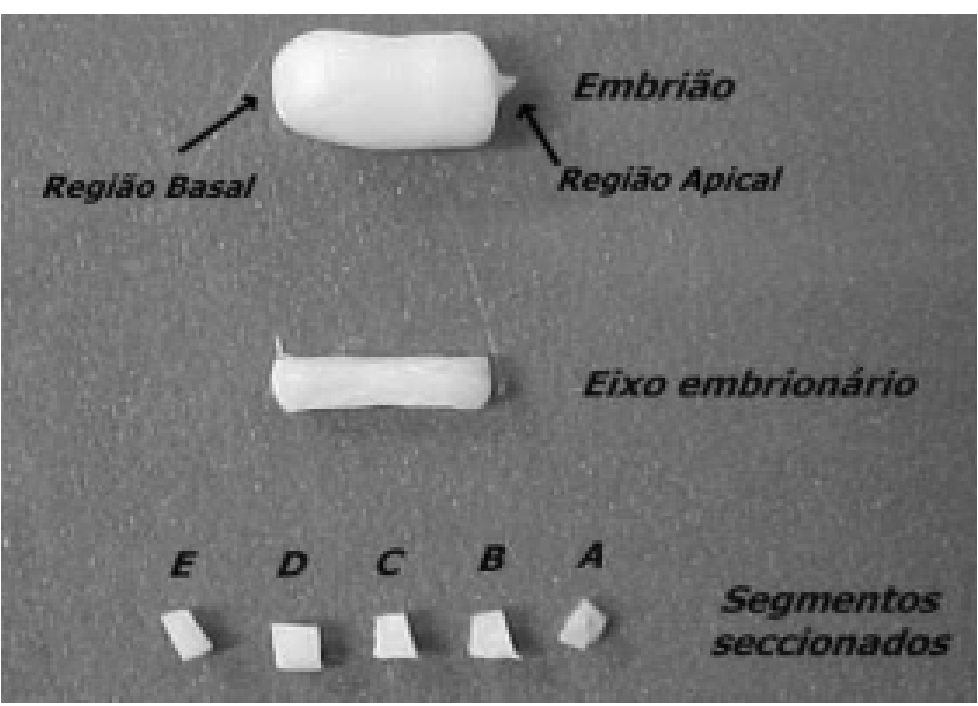

FIGURA 1 - Secção do embrião do coqueiro-Anão Verde de Jiqui, seccionado em cinco segmentos, denominados A, B, C, D e E. Embrapa Tabuleiros Costeiros, Aracaju-SE, 2002.
Aos 15 e 30 dias após a inoculação, foi determinada a porcentagem de formação de calo friável nos segmentos de eixo embrionário, nas quatro concentrações de 2,4-D. As médias foram submetidas à análise de variância e, quando significativas, foram comparadas pelo teste de Tukey, a 1\% de significância. Os dados foram transformados em $\sqrt{ } \mathrm{x}+1$.

\section{RESULTADOS E DISCUSSÃO}

Observou-se a formação de calos friáveis nos explantes originários do eixo embrionário do coqueiro, nos 15 primeiros dias após a inoculação (Tabela 1). Outros autores têm observado uma variação no tempo de início de formação de calos, de 2 a 3 meses (Rillo, 1989), 6 meses (Verdeil et al., 1992) e 4 meses (Verdeil et al., 1994) após a inoculação, em diferentes explantes. Dessa forma, o fato de obter-se sucesso na formação de calos nesses tecidos em 1/4 a 1/6 do tempo alcançado pelos autores mencionados, será de grande importância para o estabelecimento de futuros protocolos de regeneração in vitro de coqueiro.

As concentrações mais baixas de 2,4-D $\left(10^{-4}\right.$ e $\left.1,36 \times 10^{-4} \mathrm{M}\right)$ mostraram-se as mais eficientes na indução de calos em tecidos originários de eixo embrionário do coqueiro, não diferindo estatisticamente entre si (Tabela 1). Obtiveram-se uma correlação negativa entre a concentração de 2,4-D e a formação de calos friáveis (Figura 2). O explante C, na concentração de $3,62 \times 10^{-4} \mathrm{M}$, não desenvolveu calo durante o período de 15 e de 30 dias, porém apresentou $2,5 \%$ de calogênese na concentração de $4,52 \times 10^{-4} \mathrm{M}$, aos 30 dias de cultura. $\mathrm{O}$ explante $\mathrm{D}$, submetido a 2,4-D nas concentrações de $3,62 \times 10^{-4} \mathrm{e} 4,52 \times 10^{-4} \mathrm{M}$, desenvolveu baixa porcentagem de calos $(12,5$ $\%$ e $5 \%$, respectivamente), aos 15 e 30 dias de cultura. Estes resultados concordam com os obtidos por Eeuwens (1976), onde auxinas (2,4-D e ANA) estimularam o crescimento dos tecidos apenas em baixas concentrações $\left(10^{-7} \mathrm{M}\right)$ e que sua presença, em altas concentrações, no meio de cultura, foi inibitória e causou a morte dos tecidos. Entretanto, Verdeil et al. (1994) relataram o estabelecimento de calos embriogênicos e a regeneração de plântulas, a partir de explantes de inflorescência imatura, obtendo a formação dos calos, aos oito meses de cultura, sem subcultivo em níveis altos de 2,4-D.

A interação tipo de segmento $\mathrm{x}$ concentração de 2,4-D foi altamente significativa para a indução de calos. Aos 15 e 30 dias de inoculação, os segmentos A, B e E apresentaram melhor resposta quanto à formação de calos. A obtenção de maior calogênese nos segmentos $\mathrm{A}$ e B se deve, provavelmente, à sua proximidade da zona meristemática do eixo embrionário, ou seja, nas partes regenerativas competentes. Por outro lado, o desenvolvimento de calos no segmento E deve-se à sua proximidade em relação ao haustório, constatado pela aparência esponjosa do tecido característico. Nos segmentos C e D, não foi observada a formação satisfatória de calos, nas concentrações testadas nos períodos analisados, provavelmente, devido ao fato de terem sido seccionados da parte intermediária do eixo embrionário, distante dos tecidos mencionados.

TABELA 1 - Porcentagem de formação de calo friável em cinco tipos de segmentos de eixo embrionário de coqueiro-Anão Verde de Jiqui combinados com concentrações de 2,4-D, aos 15 e 30 dias de cultura. Embrapa Tabuleiros Costeiros, Aracaju-SE, 2002.

\begin{tabular}{|c|c|c|c|c|c|}
\hline \multicolumn{6}{|l|}{ Aos 15 dias } \\
\hline \multicolumn{6}{|c|}{$\%$ de Calos } \\
\hline \multicolumn{3}{|c|}{ Concentração de 2,4-D } & \multicolumn{3}{|c|}{ Posição dos Explantes } \\
\hline & A & B & $\mathrm{C}$ & $\mathrm{D}$ & $\mathrm{E}$ \\
\hline $10^{-4} \mathrm{M}$ & $97,5 \mathrm{aA}$ & $97,5 \mathrm{aA}$ & $22,5 \mathrm{cA}$ & $10 \mathrm{cA}$ & $60 \mathrm{bA}$ \\
\hline $1,36 \times 10^{-4} \mathrm{M}$ & 92,5 aA & $80 \mathrm{abA}$ & $7,5 \mathrm{acA}$ & $5 \mathrm{cA}$ & $60 \mathrm{bA}$ \\
\hline $3,62 \times 10^{-4} \mathrm{M}$ & $42,5 \mathrm{abB}$ & $10 \mathrm{cB}$ & $0 \mathrm{cA}$ & $12,5 \mathrm{bcA}$ & $45 \mathrm{aAB}$ \\
\hline $4,52 \times 10^{-4} \mathrm{M}$ & $37,5 \mathrm{aB}$ & $2,5 \mathrm{bB}$ & $0 \mathrm{bA}$ & $5 \mathrm{bA}$ & $27,5 \mathrm{abB}$ \\
\hline \multicolumn{6}{|l|}{ Aos 30 dias } \\
\hline $10^{-4} \mathrm{M}$ & $100 \mathrm{aA}$ & $97,5 \mathrm{aA}$ & $20 \mathrm{bcA}$ & $5 \mathrm{cA}$ & $55 \mathrm{abA}$ \\
\hline $1,36 \times 10^{-4} \mathrm{M}$ & $90 \mathrm{aAB}$ & $80 \mathrm{aA}$ & $15 \mathrm{bA}$ & $5 \mathrm{bA}$ & $57,5 \mathrm{aA}$ \\
\hline $3,62 \times 10^{-4} \mathrm{M}$ & $45 \mathrm{aBC}$ & $10 \mathrm{cB}$ & $0 \mathrm{cA}$ & $12,5 \mathrm{bcA}$ & $42,5 \mathrm{abA}$ \\
\hline $4,52 \times 10^{-4} \mathrm{M}$ & $37,5 \mathrm{aC}$ & $5 \mathrm{bB}$ & $2,5 \mathrm{bA}$ & $5 \mathrm{bA}$ & $30 \mathrm{abA}$ \\
\hline
\end{tabular}

Médias seguidas de mesma letra, maiúscula na vertical e minúscula na horizontal, não diferem entre si, pelo teste de Tukey, a 1\% de probabilidade. 


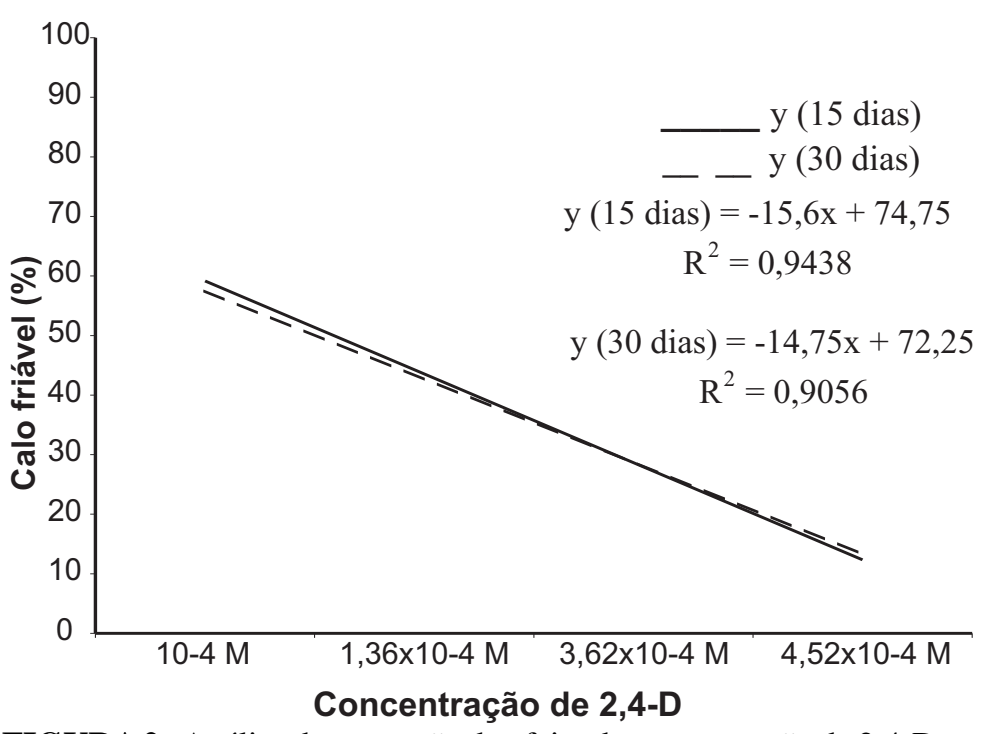

FIGURA 2 - Análise de regressão do efeito da concentração de 2,4-D na formação de calo friável de eixo embrionário de coqueiroAnão Verde de Jiqui, aos 15 e 30 dias de cultura. Embrapa Tabuleiros Costeiros, Aracaju-SE, 2002.

\section{CONCLUSÕES}

1) As concentrações de 2,4-D que melhor induzem a formação de calos, são as de $10^{-4} \mathrm{Me} 1,36 \times 10^{-4} \mathrm{M}$, em um espaço de tempo de 15 a 20 dias.

2) Forma-se calo aos 15 dias a partir de segmentos próximos à zona meristemática do eixo embrionário.

3) Os segmentos do eixo embrionário seccionados nas posições A, B (regiões apical do eixo embrionário) e E (região basal do eixo embrionário) apresentam melhores resultados para calogênese nas concentrações analisadas.

\section{REFERÊNCIAS BIBLIOGRÁFICAS}

BLAKE, J.; HORNUNG, R. Somatic embryogenesis in coconut (Cocos nucifera L.). In: S.M. JAIN, S.M..; GUPTA, P.R..; NEWTON, R.J. (Ed.) Somatic embryogenesis in woody plants. Dodrecht: Angiosperms kluwer academics, 1995, p. 327-340.

BRANTON, R.L.; BLAKE, J. In vitro plantlet development from caloid derived from immature inflorescence of Cocos nucifera L. In: SOMERS, D.A.; GENGENBACH, B.G.; BIESBOER, D.O.; HACKETT, W.P.; GREEN, C.E. (Ed.) Abstracts of VI international congress of plant tissue and cell culture. University of Minnesota, Minneapolis, p. 771-780, 1986.

BUFFARD-MOREL, J.; VERDEIL, J.L.; PANNETIER, C. Vegetative propagation of coconut palm (Cocos nucifera $\mathrm{L}$.) through somatic embryogenesis. In: INTERNATIONAL BIOTECHNOLOGY SYMPOSIUM, 8., 1988, Paris. Proceedings... p. 177.

CHAN, J.L.; SAENZ, L.; TALAVERA, C.; HORNUNG, R.; ROBERT, M.; OROPEZA, C. Regeneration of coconut (Cocos nucifera L.) from plumule explants through somatic embryogenesis. Plant Cell Reports, Berlin, v. 17, p. 515-521, 1998.

EEUWENS, C.J. Effects of organic nutrients and hormones on growth and development of tissue explants from coconut (Cocos nucifera L.) and date (Phoenix dactylifera) palms cultured in vitro. Physiologia Plantarum, Copenhagen, v. 42, p. 73-78, 1978.

EEUWENS, C.J. Mineral requirements for growth and callus initiation os tissue explants excised from mature coconut palms (Cocos nucifera) and cultured in vitro. Physiologia Plantarum, Copenhagen, v. 36, p. 23-28, 1976.

HORNUNG, R. Micropropagation of Cocos nucifera L. from plumular tissues excised from mature zygotic embryos. Plantations Recherche Developpment, Paris, v. 2, n. 2, p. 38-41, 1995.

MOREL, G.; WETMORE, R.M. Fern callus tissue culture. American Journal of Botany, Colombia, v. 38, p. 141-143, 1951.

PANNETIER, C.; BUFFARD-MOREL, J. Coconut palm (Cocos nucifera L.). In: BAJAJ, Y.P.S. Biotechnology in agriculture and forestry: Berlin: Springer Verlag, 1986. p. 430-458.

RILLO, E.P. A non-destructive technique for collecting immature coconut inflorescence for tissue culture. Philippine Journal of Coconut Studies, Quezon City, v. 4, p. 16-17, 1989.

RILLO, E.P.; PALOMA, M.B.F. Comparison of three media formulations for in vitro culture of coconut embryos. Oléagineux, Paris, v. 45, p. 319-323, 1990.

SÁ, M.E.L. de; CANÇADO, G.M. de A.; SOUZA, C.M. de. Cultivo de plantas in vitro e suas aplicações. Informe Agropecúario, Belo Horizonte, v. 21, n. 204, p. 116-123, 2000.

SIQUEIRA, L.A. de; SIQUEIRA, E.R. de; RIBEIRO, F.E. Comportamento de híbridos de coqueiro no Nordeste do Brasil. Plantation Recherche Revelopment, Paris, v.2, n.1, p.48-53. 1995.

VERDEIL, J.L.; HUET, C.; GROSDEMANGE, F.; BUFFARD-MOREL, J. Plant regeneration from cultured immature inflorescences coconut (Cocos nucifera L.): Evidence for somatic embryogenesis. Plant Cell Reports, Berlin, v. 13, p. 218-221, 1994.

VERDEIL, J.L.; HUET, C.; GROSDEMANGES, F.; RIVAL, A; BUFFARDMOREL, J. Embryogenèse Somatique du Cocotier (Cocos nucifera L.): Obtencion de plusieurs clones de vitro plants. Oléagineux, Paris, v. 47, n. 7, p. 465-467, 1992. 